\title{
PROSPECT OF NATURAL REGENERATION OF TREE SPECIES IN HAZARIKHIL WILDLIFE SANCTUARY OF CHATTOGRAM, BANGLADESH
}

\author{
Rahman, M. A., M. A. Alim, M. K. Hossain and M. A. Hossain \\ Institute of Forestry and Environmental Sciences, Chittagong University, Chattogram-4331, Bangladesh
}

\begin{abstract}
Natural regeneration of tree species is the major means of understanding the restoration potentiality of a secondary forest. Natural regeneration of a forest is a tool for measuring the health of the forest ecosystem. Natural regeneration status of tree species in Hazarikhil Wildlife Sanctuary (HWS) in Chittagong North Forest Division, Bangladesh was assessed laying 75 systematic quadrats of $4 \mathrm{~m} \times 4 \mathrm{~m}$ in size. A total of 90 regenerating tree species belonging to 34 families was identified from the HWS. Euphorbiaceae family possessed maximum regenerating tree species (14 species) followed by Mimosaceae (7), Lauraceae and Meliaceae (6 species each), and Moraceae (5 species). The overall seedling density was 7,083 per ha where Ficus hispida showed the highest number of seedlings (792 per ha) followed by Quercus sp. (475), Ficus religiosa (408), Lithocarpus elegans (375) and Lepisanthes rubiginosa (367). The number of Ficus hispida seedlings per ha was higher due to high coppicing ability. Lepisanthes rubiginosa attained maximum IVI (27.59) followed by Ficus hispida (21.18) and Quercus oxyodon (13.32). The seedlings of Aegle marmelos, Lithocarpus sp., Flacourtia jangomas, Albizia odoratissima, Acronychia padunculata, Chaetocarpus castanicarpus, Maesa paniculata, Crypteronia paniculata, Streblus asper and Mussaenda roxburghii were also found common in the study area. The findings will create baseline information of regenerating tree species, composition, diversity and population structure which can be used for monitoring future changes as well as taking policy decisions for the management of this Wildlife Sanctuary.
\end{abstract}

Key words: Natural regeneration; Tree diversity; Protected Areas; Hazarikhil Wildlife Sanctuary; Forest restoration.

\section{INTRODUCTION}

Bangladesh is situated in the transitional zone of the flora and fauna of the Indian subcontinent and Southeast Asia and is part of the Indo-Burma biodiversity hotspot which is one of the ten global hot-spot areas for biodiversity (Mittermeier et al. 1998, Stanford 1991). The total area of Bangladesh is 14.757 million hectares, of which forest land accounts for almost 17.5\% (2.53 million ha) (BFD 2017). Total forest land includes classified and unclassified state lands, homestead forests, and tea and rubber gardens. Bangladesh has a rich biological heritage containing about 3,723 species of angiosperms (Hossain et al. 2017). During the last few decades, most of the tropical forests including Bangladesh were negatively changed by both biotic and abiotic disturbances which ultimately affected the regeneration and population dynamics of the remnant forests (Kwit and Platt 2003, Shafroth et al. 2002). The annual rate of deforestation in Bangladesh was 2000 ha per year in 2000-2005 (FAO 2016). In such rates, Bangladesh's forest is likely to disappear by the next 35-40 years or earlier (IMF 2013). The rapid loss and degradation of forests in Bangladesh are going on at an alarming rate causing forest biodiversity depletion (Hossain 2001, Rashid et al. 2000). Bangladesh Government has explored and implemented some alternative forest management strategies for the conservation of forests as well as biodiversity of the country (Abdullah et al. 2007). Forests or part of forests have been declared as Protected Areas (PAs) according to the IUCN categories. Currently, Bangladesh possesses a total of 55 PAs among which 17 National Parks, 20 Wildlife Sanctuaries and the rests are Safari parks. Beside these, special biodiversity conservation areas, botanical gardens, eco-park, marine PA, Vulture Safe Zone, and Aviary park are also maintained. Protected Areas cover about 618254 hectares covering $4.19 \%$ forest land of Bangladesh (BFD 2017). 
Forestry is an important sector in Bangladesh economy, which contributes about $1.28 \%$ of the country's gross domestic product (BBS 2012). The hill forests of the country are rich in biodiversity and support almost $80 \%$ of the country's total biodiversity (Nishat and Biswas 2005). Natural regeneration of tree species is crucial for forest conservation, maintenance of biodiversity and also for forest ecosystems. Depending on management objectives, it is important to maintain the process of forest renewal by appropriate natural and artificial regeneration. The previous silvicultural system of clear felling accelerates the loss of seedlings and saplings as well as disturbs the natural condition of the natural forests and hence the ecosystem (Haque and Alam 1988). PAs play a key role to reduce deforestation, habitat degradation and biodiversity loss. The primary aim of establishing Hazarikhil Wildlife Sanctuary as PA was to strengthen the conservation of the existing flora and fauna of the area. In the recent years few studies were carried out to investigate the regeneration of tree species and their population structure in Babu Para Village Common Forest of Bandarban (Kamruzzaman et al. 2018), Chunati Wildlife Sanctuary (Hossain and Hossain 2014), Dudhpukuria-Dhupachari Wildlife Sanctuary (Hossain et al. 2013), Northeastern region of Bangladesh (Rahman et al. 2011) and denuded hills of Chittagong (Ahmed et al. 1992). However, the information on natural regeneration status of different tree species in Hazarikhil Wildlife Sanctuary is not available. The pattern of natural regeneration is important in adopting forest management decisions (Hossain et al. 1999). In addition, floristic composition, diversity and their quantitative structure are vital for understanding the functioning and structure of forest ecosystems which ultimately help in protected area conservation and management (Reddy et al. 2011). Importance of natural regeneration is immense as it helps to reduce plantation establishment cost, time, and quick restoration with indigenous species. Considering the importance, the present initiative was to assess the natural regeneration potential of Hazarikhil Wildlife Sanctuary in Chattogram.

\section{Study area}

\section{MATERIAL AND METHODS}

Hazarikhil Wildlife Sanctuary (HWS) covering an area of 1,177 ha is located in the North-West of Fatikchari Upazila in Chattogram district and consists of two beats, namely Fatikchari beat and Hazarikhil beat. It is under the jurisdiction of Chittagong North Forest Division. HWS is covered by tropical moist semi-evergreen forest comprising of hills (altitude 20-110m), hillocks and plain lands (Figure 1). The forest is mostly a secondary one as the area experiences extensive removal of trees and forest resources illegally. Forest department conducted some plantations with both native and exotic species to cover the gap areas. The area is traversed by numerous creeks. Soil is loamy and yellowishbrown to reddish-brown which grade into broken shale or sandstone at a depth of $30-120 \mathrm{~cm}$ (Osman 2013). The soil condition and thickness of top humus layer varies from place to place depending on topography. The mean annual temperature of HWS and adjacent area ranges from $19.9{ }^{\circ} \mathrm{C}$ to $28.3{ }^{\circ} \mathrm{C}$, while the mean annual rainfall is about $2900 \mathrm{~mm}$, and mean annual relative humidity is approximately $78 \%$. The climate of the area is characterized by three distinct seasons- a hot and humid summer from March to June, a cool and rainy monsoon season from June to October, and a cool and dry winter from October to March (Shahid 2010).

Study design

A systematic quadratic sampling method (Williams 1991) was used to determine the regeneration status of the tree species of Hazarikhil Wildlife Sanctuary. Sample plots were laid on map at equal intervals encompassing the whole area of HWS. Some of the plots were not accessible due to steep terrain, deep gorge and other physical reasons. However, seventy-five sample plots of size $4 \mathrm{~m} \times 4 \mathrm{~m}(45$ 
from Hazarikhil and 30 from Fatikchari beat) were surveyed for the regeneration study from January 2016 to April 2017.

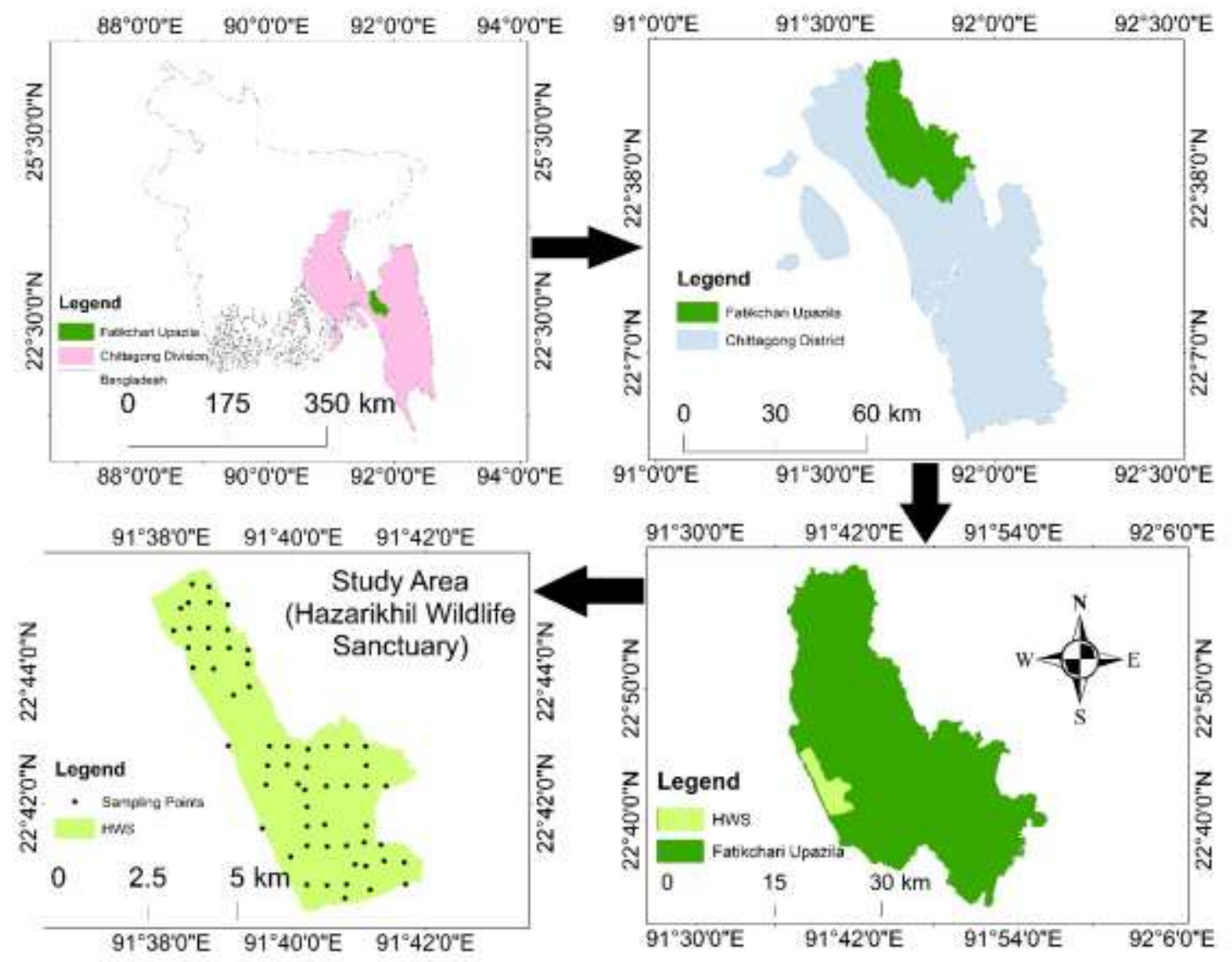

Fig. 1. Location map of Hazarikhil Wildlife Sanctuary

\section{Field data collection}

The regenerations of the tree species having $\mathrm{dbh}<2 \mathrm{~cm}$ were considered as seedlings. The seedlings of tree species were identified by local experts in the field and verifieded with the help of taxonomists in the Department of Botany, Chittagong University and Bangladesh Forest Research Institute (BFRI). The seedlings were counted by species and the data were analyzed following some formulae (Table 1). Regeneration from the seed, coppice or root sucker was also recorded as the source of seedlings.

\section{Data analysis}

The identified tree species were compiled using the latest binomial names following Encyclopedia of Flora and Fauna of Bangladesh (Ahmed et al. 2008). Phytosociological attributes including density, frequency, abundance, family relative density, and importance value index were estimated following Williams (1991) (Table 1). Different biological diversity indices, i.e. Shannon-Wiener's diversity index (H), Simpson's dominance index (D), Margalef's species richness index (R), Simpson's species evenness index (E) were studied following Margalef (1958), Pielou (1984), Shannon and Weiner (1963) and Simpson (1949). 
Table 1. Formulae used for the analysis of the field data.

\begin{tabular}{|l|c|c|}
\hline Variable & Equation & Reference \\
\hline Density, $\mathrm{D}$ & $D=\frac{n}{m}$ & Shukla and Chandel 2000 \\
\hline Relative Density, $\mathrm{R}_{\mathrm{d}}$ & $\mathrm{R}_{\mathrm{d}}=\frac{q}{z} \times 100$ & Dallmeier et al. 1992, Misra 1968 \\
\hline Frequency, $\mathrm{F}$ & $\mathrm{F}=\frac{x}{m}$ & Shukla and Chandel 2000, Elzinga et al. 1998 \\
\hline Relative Frequency, $\mathrm{R}_{\mathrm{f}}$ & $\mathrm{R}_{\mathrm{f}=\frac{f}{f t}}$ & Dallmeier et al. 1992, Misra 1968 \\
\hline Abundance, $\mathrm{A}$ & $\mathrm{A}=\frac{n}{x}$ & Shukla and Chandel 2000 \\
\hline Relative abundance, $\mathrm{R}_{\mathrm{a}}$ & $\mathrm{R}_{\mathrm{a}=\frac{a}{a t} \times 100}$ & Shukla and Chandel 2000 \\
\hline Importance Value Index & $\mathrm{IVI}=\mathrm{R}_{\mathrm{d}}+\mathrm{R}_{\mathrm{f}}+\mathrm{R}_{\mathrm{a}}$ & Shukla and Chandel 2000, Dallmeier et al. 1992 \\
\hline Family relative density, $\mathrm{F}_{\mathrm{d}}$ & $\mathrm{F}_{\mathrm{d}}(\%)=\mathrm{N}_{\mathrm{f}} / \mathrm{T}_{\mathrm{i}} \times 100$ & Mori et al. 1983 \\
\hline Family relative diversity, $\mathrm{F}_{\mathrm{r}}$ & $\mathrm{F}_{\mathrm{r}}(\%)=\mathrm{N}_{\mathrm{s}} / \mathrm{T}_{\mathrm{s}} \times 100$ & Margalef 1958 \\
\hline Margalef's species richness index, $\mathrm{R}$ & $\mathrm{R}=\frac{(S-1)}{L N(N)}$ & Shannon and Weiner, 1963 \\
\hline Shannon-Wiener's diversity index, $\mathrm{H}$ & $\mathrm{H}=-\sum_{i=1}^{n} P_{i} \ln P_{i}$ & Simpson, 1949 \\
\hline Simpson's diversity index, $\mathrm{D}$ & $\mathrm{D}=\sum_{i=1}^{n} P_{i}^{2}$ & Pielou, 1984 \\
\hline Species (Pielou's) evenness index, $\mathrm{E}$ & $\mathrm{E}=\frac{H}{L n(S)}$ & \\
\hline
\end{tabular}

$\mathrm{H}=$ Shannon-Wiener's diversity index; $\mathrm{N}=$ Total no. of individuals of all the species; $\mathrm{Pi}=$ Number of individuals of $i^{\text {th }}$ species/Total number of individuals; $S=$ Total number of species; $N_{f}=$ No. of individuals in a family; $T_{i}=T$ Total No. of individuals; $\mathrm{N}_{\mathrm{s}}=$ No. of species; $\mathrm{T}_{\mathrm{s}}=$ Total number of species; $\mathrm{n}=$ Total no. of individuals of a species in all the quadrats; $\mathrm{m}=$ Total No. of quadrats studied; $\mathrm{q}=$ Total No. of individuals of a species; $\mathrm{z}=$ Total No. of individuals of all the species; $x=$ Total No. of quadrats in which the species occurs; $f=$ Frequency of one species; $f_{t}$ $=$ Total frequency $; \mathrm{a}=$ Abundance of one species; $\mathrm{a}_{\mathrm{t}}=$ Total abundance $; \mathrm{b}=$ Total basal area of a species in all the quadrats; $\mathrm{y}=$ Total basal area of all the species in all the quadrats.

\section{Natural regeneration of the tree species}

\section{RESULTS AND DISCUSSION}

Altogether 90 regenerating tree species belonging to 77 genera and 34 families were listed from the HWS during the study. Among the 34 families, top 10 families are presented by more than $61 \%$ species whereas, only one species occurred under 16 families (Table 2). Euphorbiaceae family dominated with 14 species followed by Mimosacea ( 8 species), Lauraceae and Meliaceae (6 species each), and Moraceae (5 species). The number of regenerating tree species composition is higher than that of some similar forests of nearby areas, e.g. 29 species in Bamu forest reported by Motaleb and Hossain (2007), 55 species by Rahman et al. (2011) from Khadimnagar National Park, and 35 species by Kamruzzaman et al. (2018) from Babu Para Village Common Forest. However, the composition is quite lower than that of two adjacent protected areas of southeastern Bangladesh, e.g. 120 species in DudhpukuriaDhopachari Wildlife Sanctuary (Hossain et al. 2013) and 105 species in Chunati Wildlife Sanctuary (Hossain and Hossain 2014). The anthropogenic interferences through illegal removal of mother trees, forest fire as physically observed during the study period, exotic species plantation, etc. may have decreased the natural regeneration. Euphorbiaceae, Moraceae and Meliaceae families also reported as dominant families in the mentioned forests. Though tree species of Dipterocarpaceae was found dominant in both Dudhpukuria-Dhopachari and Chunati Wildlife Sanctuary whereas in the HWS Dipterocarps are very rare except the few individuals in the forest beat office compound. 
Table 2. Individuals per hectare, Relative Density (RD), Relative Frequency (RF), Relative Abundance (RA) and Importance Value Index (IVI) of the regenerating tree species of Hazarikhil WS.

\begin{tabular}{|c|c|c|c|c|c|c|}
\hline Scientific name & Family & Seedlings/ha & RD (\%) & RF (\%) & RA (\%) & IVI \\
\hline Abroma augusta (L.) L.f & Sterculiaceae & 8.33 & 0.12 & 0.26 & 0.50 & 0.88 \\
\hline Acacia auriculiformis A. Cunn ex Benth. et Hook. & Mimosaceae & 16.67 & 0.24 & 0.52 & 0.50 & 1.26 \\
\hline Acronychia pedunculata (L.) Miq. & Rutaceae & 8.33 & 0.12 & 0.26 & 0.50 & 0.88 \\
\hline Actinodaphne angustifolia Nees & Lauraceae & 183.33 & 2.59 & 2.59 & 1.11 & 6.29 \\
\hline Aegle marmelos (L.) Corr. & Rutaceae & 8.33 & 0.12 & 0.26 & 0.50 & 0.88 \\
\hline Albizia chinensis (Osbeck) Merr. & Mimosaceae & 16.67 & 0.24 & 0.26 & 1.01 & 1.50 \\
\hline Albizia odoratissima (L. f.) Benth. & Mimosaceae & 16.67 & 0.24 & 0.26 & 1.01 & 1.50 \\
\hline Albizia procera (Roxb.) Benth & Mimosaceae & 83.33 & 1.18 & 1.30 & 1.01 & 3.48 \\
\hline Albizia richardiana (Voigt) King \& prain & Mimosaceae & 33.33 & 0.47 & 0.26 & 2.01 & 2.74 \\
\hline Alstonia scholaris (L.) R. Br. & Apocynaceae & 108.33 & 1.53 & 0.52 & 3.27 & 5.32 \\
\hline Antidesma bunius (L.) Spreng. & Euphorbiaceae & 8.33 & 0.12 & 0.26 & 0.50 & 0.88 \\
\hline Antidesma ghaesambilla Gaertn. & Euphorbiaceae & 8.33 & 0.12 & 0.26 & 0.50 & 0.88 \\
\hline Aphanamixis polystachya (Wall.) Parker. & Meliaceae & 41.67 & 0.59 & 1.04 & 0.63 & 2.25 \\
\hline Aporosa dioica (Roxb.) Muell.-Arg. & Euphorbiaceae & 150.00 & 2.12 & 2.33 & 1.01 & 5.46 \\
\hline Aporosa wallichii Hook. f. & Euphorbiaceae & 158.33 & 2.24 & 2.85 & 0.87 & 5.95 \\
\hline Artocarpus chama Buch.-Ham & Moraceae & 41.67 & 0.59 & 1.04 & 0.63 & 2.25 \\
\hline Baccaurea ramiflora Lour. & Euphorbiaceae & 33.33 & 0.47 & 0.78 & 0.67 & 1.92 \\
\hline Bischofia javanica Blume & Euphorbiaceae & 58.33 & 0.82 & 0.52 & 1.76 & 3.10 \\
\hline Brownlowia elata Roxb. & Tiliaceae & 75.00 & 1.06 & 1.04 & 1.13 & 3.23 \\
\hline Callicarpa macrophylla Vahl. & Verbenaceae & 41.67 & 0.59 & 1.04 & 0.63 & 2.25 \\
\hline Canarium resiniferum Brace $e x$ king. & Burseraceae & 8.33 & 0.12 & 0.26 & 0.50 & 0.88 \\
\hline Carallia brachiata (Lour.) Merr. & Rhizophoraceae & 8.33 & 0.12 & 0.26 & 0.50 & 0.88 \\
\hline Chaetocarpus castanocarpus (Roxb.) Thw. & Euphorbiaceae & 16.67 & 0.24 & 0.26 & 1.01 & 1.50 \\
\hline Chukrasia tabularis A. Juss. & Meliaceae & 8.33 & 0.12 & 0.26 & 0.50 & 0.88 \\
\hline Cinnamomum iners Reinw. ex Blume & Lauraceae & 8.33 & 0.12 & 0.26 & 0.50 & 0.88 \\
\hline Clausena excavata Burm. & Rutaceae & 308.33 & 4.35 & 3.63 & 1.33 & 9.31 \\
\hline Cordia dichotoma Forst. f. & Boraginaceae & 8.33 & 0.12 & 0.26 & 0.50 & 0.88 \\
\hline Crypteronia paniculata Blume & Crypteroniaceae & 16.67 & 0.24 & 0.26 & 1.01 & 1.50 \\
\hline Dehaasia kurzii King & Lauraceae & 8.33 & 0.12 & 0.26 & 0.50 & 0.88 \\
\hline Derris robusta (Roxb. ex DC) Benth. & Fabaceae & 8.33 & 0.12 & 0.26 & 0.50 & 0.88 \\
\hline Diospyros malabarica (Desr.) Kostel. & Ebenaceae & 16.67 & 0.24 & 0.52 & 0.50 & 1.26 \\
\hline Dipterocarpus costatus Gaertn. & Dipterocarpaceae & 66.67 & 0.94 & 1.55 & 0.67 & 3.17 \\
\hline Elaeocarpus tectorius (Lour.) Poir. & Elaeocarpaceae & 8.33 & 0.12 & 0.26 & 0.50 & 0.88 \\
\hline Eurya acuminata DC. & Theaceae & 8.33 & 0.12 & 0.26 & 0.50 & 0.88 \\
\hline Ficus hispida L.f. & Moraceae & 791.67 & 11.2 & 8.55 & 1.45 & 21.18 \\
\hline Ficus racemosa L. var. Miquelli & Moraceae & 66.67 & 0.94 & 0.78 & 1.34 & 3.06 \\
\hline Ficus religiosa $\mathrm{L}$. & Moraceae & 408.33 & 5.76 & 5.18 & 1.23 & 12.18 \\
\hline Flacourtia jangomas (Lour.) Raeusch. & Flacourtiaceae & 8.33 & 0.12 & 0.26 & 0.50 & 0.88 \\
\hline Garcinia cowa Roxb. ex DC. & Clusiaceae & 50.00 & 0.71 & 0.78 & 1.01 & 2.49 \\
\hline Glochidion multiloculare (Roxb. ex Willd.) Muell.-Arg. & Euphorbiaceae & 8.33 & 0.12 & 0.26 & 0.50 & 0.88 \\
\hline Grewia nervosa (Lour.) Panigrahi & Tiliaceae & 300.00 & 4.24 & 4.92 & 0.95 & 10.1 \\
\hline Holarrhena antidysenterica (L.) Wall. ex Decne & Apocynaceae & 8.33 & 0.12 & 0.26 & 0.50 & 0.88 \\
\hline Hopea odorata Roxb. & Dipterocarpaceae & 8.33 & 0.12 & 0.26 & 0.50 & 0.88 \\
\hline Hydnocarpus kurzii (King) Warb. & Flacourtiaceae & 208.33 & 2.94 & 3.37 & 0.97 & 7.28 \\
\hline Lagerstroemia speciosa (L.) Pers. & Lythraceae & 25.00 & 0.35 & 0.26 & 1.51 & 2.12 \\
\hline Lannea coromandelica (Houtt.) Merr. & Anacardiaceae & 33.33 & 0.47 & 0.78 & 0.67 & 1.92 \\
\hline Lepisanthes rubiginosa (Roxb.) Leenhouts & Sapindaceae & 366.67 & 5.18 & 0.26 & 22.16 & 27.59 \\
\hline Lithocarpus elegans var. brevipetiolata & Fagaceae & 375.00 & 5.29 & 3.63 & 1.62 & 10.54 \\
\hline Lithocarpus fenestratus (Roxb.) Rehder & Fagaceae & 8.33 & 0.12 & 0.26 & 0.50 & 0.88 \\
\hline Litsea glutinosa (Lour.) C. B. Robinson & Lauraceae & 75.00 & 1.06 & 1.81 & 0.65 & 3.52 \\
\hline Litsea monopetala (Roxb.) Pers. & Lauraceae & 16.67 & 0.24 & 0.52 & 0.50 & 1.26 \\
\hline Macaranga denticulata (Blume) Muell.-Arg. & Euphorbiaceae & 200.00 & 2.82 & 2.85 & 1.10 & 6.77 \\
\hline
\end{tabular}




\begin{tabular}{|c|c|c|c|c|c|c|}
\hline Maesa paniculata A. DC. & Myrsinaceae & 50.00 & 0.71 & 1.04 & 0.76 & 2.50 \\
\hline Mallotus phillippensis (Lamk.) Muell.-Arg & Euphorbiaceae & 91.67 & 1.29 & 1.30 & 1.11 & 3.70 \\
\hline Mallotus tetracoccus (Roxb.) Kurz & Euphorbiaceae & 8.33 & 0.12 & 0.26 & 0.50 & 0.88 \\
\hline Melia azedarach $\mathrm{L}$. & Meliaceae & 8.33 & 0.12 & 0.26 & 0.50 & 0.88 \\
\hline Morinda angustifolia Roxb. & Rubiaceae & 125.00 & 1.76 & 1.04 & 1.89 & 4.69 \\
\hline Mussaenda roxburghii Hook. F. & Rubiaceae & 8.33 & 0.12 & 0.26 & 0.50 & 0.88 \\
\hline Oroxylum indicum (L.) Benth. ex Kurz & Bignoniaceae & 8.33 & 0.12 & 0.26 & 0.50 & 0.88 \\
\hline Palaquium polyanthum (Wall. ex DC.) Engler. & Sapotaceae & 41.67 & 0.59 & 1.04 & 0.63 & 2.25 \\
\hline Persea bombycina (King ex Hook.f.) Kosterm. & Lauraceae & 8.33 & 0.12 & 0.26 & 0.50 & 0.88 \\
\hline Pithecellobium angulatum Benth. & Mimosaceae & 8.33 & 0.12 & 0.26 & 0.50 & 0.88 \\
\hline Protium serratum (Wall. ex Colebr.) Engl. & Burseraceae & 133.33 & 1.88 & 2.33 & 0.90 & 5.11 \\
\hline Pterospermum semisagittatum Buch.-Ham. ex Roxb. & Sterculiaceae & 116.67 & 1.65 & 1.55 & 1.17 & 4.38 \\
\hline Quercus gomeziana A. Camus & Fagaceae & 50.00 & 0.71 & 1.30 & 0.60 & 2.61 \\
\hline Quercus oxyodon Miq. & Fagaceae & 475.00 & 6.71 & 5.18 & 1.44 & 13.32 \\
\hline Samanea saman (Jacq.) Merr. & Mimosaceae & 25.00 & 0.35 & 0.78 & 0.50 & 1.63 \\
\hline Sapium baccatum Roxb. & Euphorbiaceae & 8.33 & 0.12 & 0.26 & 0.50 & 0.88 \\
\hline Sarcochlamys pulcherrima Gaud. & Urticaceae & 8.33 & 0.12 & 0.26 & 0.50 & 0.88 \\
\hline Shorea robusta Roxb. ex Gaertn. f. & Dipterocarpaceae & 25.00 & 0.35 & 0.26 & 1.51 & 2.12 \\
\hline Sterculia villosa Roxb. ex Smith. & Sterculiaceae & 8.33 & 0.12 & 0.26 & 0.50 & 0.88 \\
\hline Stereospermum colais (Buch.-Ham. ex Dillw.) Mabb. & Bignoniaceae & 25.00 & 0.35 & 0.78 & 0.50 & 1.63 \\
\hline Streblus asper Lour. & Moraceae & 16.67 & 0.24 & 0.26 & 1.01 & 1.50 \\
\hline Suregada multiflora (A. Juss.) Bail. & Euphorbiaceae & 183.33 & 2.59 & 3.63 & 0.79 & 7.01 \\
\hline Swietenia mahagoni (L.) Jacq. & Meliaceae & 8.33 & 0.12 & 0.26 & 0.50 & 0.88 \\
\hline Syzygium fruticosum DC. & Myrtaceae & 16.67 & 0.24 & 0.52 & 0.50 & 1.26 \\
\hline Syzygium cumini (L.) Skeels & Myrtaceae & 83.33 & 1.18 & 1.81 & 0.72 & 3.71 \\
\hline Syzygium firmum Thw. & Myrtaceae & 16.67 & 0.24 & 0.26 & 1.01 & 1.50 \\
\hline Tectona grandis L.f. & Verbenaceae & 16.67 & 0.24 & 0.52 & 0.50 & 1.26 \\
\hline Terminalia bellirica (Gaertn.) Roxb. & Combretaceae & 8.33 & 0.12 & 0.26 & 0.50 & 0.88 \\
\hline Terminalia chebula Retz. & Combretaceae & 8.33 & 0.12 & 0.26 & 0.50 & 0.88 \\
\hline Toona ciliata Roem & Meliaceae & 258.33 & 3.65 & 3.11 & 1.30 & 8.06 \\
\hline Trema orientalis (L.) Blume & Ulmaceae & 158.33 & 2.24 & 3.11 & 0.80 & 6.14 \\
\hline Trevesia palmata (Roxb. ex Lindl.) Vis. & Araliaceae & 25.00 & 0.35 & 0.26 & 1.51 & 2.12 \\
\hline Trewia nudiflora L. & Euphorbiaceae & 8.33 & 0.12 & 0.26 & 0.50 & 0.88 \\
\hline Vitex glabrata R.Br. & Verbenaceae & 133.33 & 1.88 & 2.07 & 1.01 & 4.96 \\
\hline Walsura robusta Roxb. & Meliaceae & 50.00 & 0.71 & 0.52 & 1.51 & 2.73 \\
\hline Wendlandia tinctoria (Roxb.) DC. & Rubiaceae & 175.00 & 2.47 & 1.81 & 1.51 & 5.79 \\
\hline Wrightia arborea (Dennst.) Mabb. & Apocynaceae & 100.00 & 1.41 & 0.52 & 3.02 & 4.95 \\
\hline Xylia xylocarpa (Roxb.) Taub. & Mimosaceae & 25.00 & 0.35 & 0.52 & 0.76 & 1.63 \\
\hline Total & & 7083.33 & 100 & 100 & 100 & 300 \\
\hline
\end{tabular}

Phytosociological attributes of naturally regenerating tree species

The quantitative structure of naturally regenerating tree species in the HWS is analyzed on the basis of Density, Relative Density (RD), Relative Frequency (RF), Relative Abundance (RA) and Importance Value Index (IVI). The highest number of seedlings per hectare was found in Ficus hispida (792) followed by Quercus oxyodon (475), Ficus religiosa (408), Lithocarpus elegans (375) and Lepisanthes rubiginosa (367) (Figure 2 and Table 2). The lowest number (8) of seedlings per hectare was recorded in Aboroma augusta, Chukrasia tabularis, Aegle marmelos, Hopea odorata and 28 more species. Maximum (11.18\%) RD was recorded in Ficus hispida followed by Quercus oxyodon (6.71\%), Ficus religiosa (5.76\%), L. elegans (5.29\%) and L. rubiginosa (5.18\%). Maximum (8.55\%) RF was recorded in F. hispida followed by Quercus oxyodon, F. religiosa (each 5.18\%) and Grewa nervosa (4.92\%). The highest $(22.16 \%)$ relative abundance was shown by Lepisanthes rubiginosa followed by Alstonia scholaris (3.27\%), Wrightia arborea (3.02\%), Albizia richardiana (2.01\%) and Morinda angustifolia (1.89\%) (Table 2). Maximum Importance Value Index (IVI) was found in L. rubiginosa (27.59 out of 
300) followed by F. hispida (21.18), Quercus oxyodon (13.32), F. religiosa (12.18), L. elegans (10.54) and G. nervosa (10.11) (Table 2). Unfortunately, the population of few species is so poor that natural regeneration seems to be inadequate. Some keystone tree species, e.g. Anisoptera scaphula, Swintonia floribunda and Michelia champaca are very rare in the forests. Very few individuals of Sterculia villosa, Spondias pinnata and Lannea coromandelica are only available in the forest office compound without having any natural regeneration. These may be due to human disturbances and grazing animals from the adjacent villages.

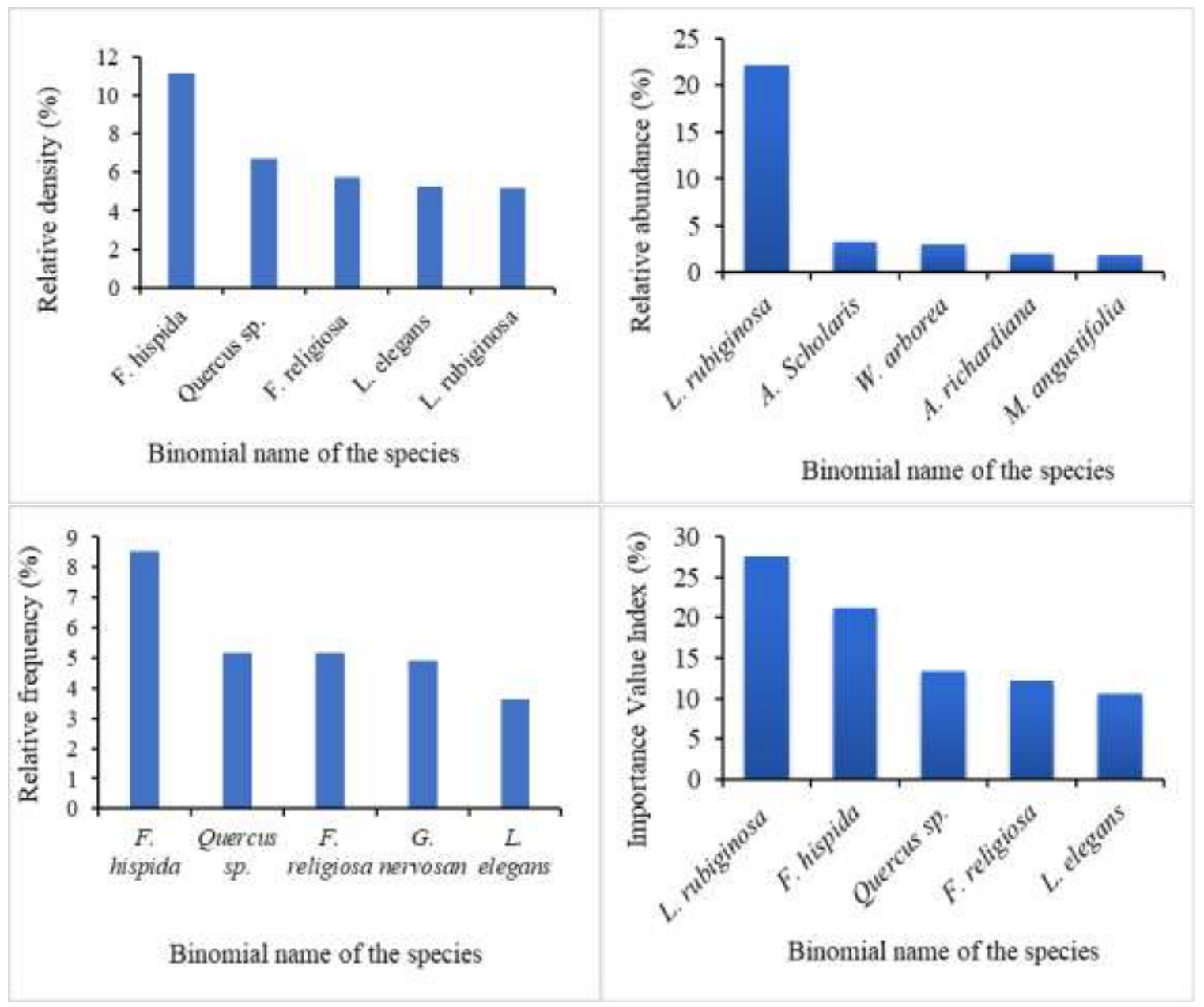

Fig. 2. Phytosociological attributes of 5 dominant regenerating tree species in the HWS

\section{Natural regeneration potential of the families}

About $44 \%$ (16) families were represented by only one species and 38\% (13) by more than two species (Table 2). Highest (18.71\%) Family Relative Density (FRD) was represented by Moraceae followed by Euphorbiaceae (13.29\%) and Fagaceae (12.82\%). Family Relative Diversity Index (FRDI) was found maximum for Euphorbiaceae (15.56\%). Maximum Family Importance Value (FIV) index was found (28.85) for Euphorbiaceae followed by Moraceae (24.26), Fagaceae (17.27), Meliaceae (11.96) and Lauraceae (10.90) (Table 3). The number of species and tree individuals, FRD, FRDI, and FIV of 10 dominant regenerating tree families of HWS are shown in Fig. 3. 
Table 3. Important top 10 families of the regenerating species and their population structure in the HWS.

\begin{tabular}{lcccc}
\hline Family & No. of Individual seedlings & FRD (\%) & FRDI (\%) & FIV \\
\hline Moraceae & 159 & 18.71 & 5.56 & 24.26 \\
Euphorbiaceae & 113 & 13.29 & 15.56 & 28.85 \\
Fagaceae & 109 & 12.82 & 4.44 & 17.27 \\
Tiliaceae & 45 & 5.29 & 2.22 & 7.52 \\
Meliaceae & 45 & 5.29 & 6.67 & 11.96 \\
Sapindaceae & 44 & 5.18 & 1.11 & 6.29 \\
Rutaceae & 39 & 4.59 & 3.33 & 7.92 \\
Rubiaceae & 37 & 4.35 & 3.33 & 7.69 \\
Lauraceae & 36 & 4.24 & 6.67 & 10.90 \\
Mimosaceae & 27 & 3.18 & 8.89 & 12.07 \\
\hline Total & $\mathbf{8 5 0}$ & $\mathbf{1 0 0}$ & $\mathbf{1 0 0}$ & $\mathbf{2 0 0}$ \\
\hline
\end{tabular}

FRD $=\overline{\text { Family relative density; FRDI = Family Relative Diversity Index; } \text { and FIV = Family Importance Value Index }}$

Biological diversity indices of regenerating tree species

The Shannon-Wiener Diversity Index, Simpson's Dominance Index, Pielou's Evenness Index, and Margalef's Species Richness Index showed that the overall regeneration species diversity is moderate in the HWS in terms of species diversity, dominance, evenness, and species richness. However, recent reports on similar diversity indices from the protected areas of similar geographic and ecological features, i.e. Chunati Wildlife Sanctuary and Dudhpukuria-Dhopachari Wildlife Sanctuary are comparatively higher than that of the HWS (Table 4). The probable reasons of poor regeneration diversity may be due to frequent fire and human interferences in the form of removal of trees.

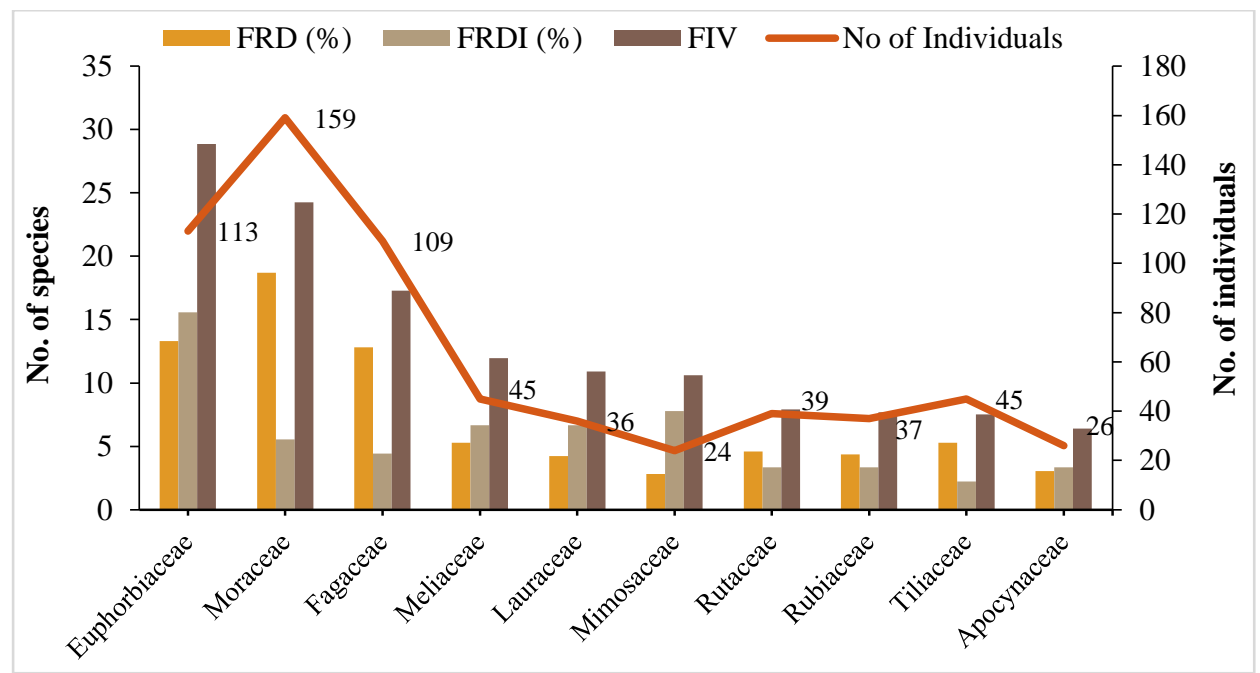

Fig. 3. Family Relative Density (FRD), Family Relative Diversity (FRDI), Family Importance Value (FIV) index and no. of individual of 10 dominant regenerating trees in HWS.

The study found that regeneration of tree species is originated either from soil seed banks or from the coppice. The study shows that only $19 \%$ of the regeneration is coppice-origin and the rest $81 \%$ regeneration is seed origin. Information on regeneration potential leads to conservation measures of biological diversity. It is an important indicator for evaluating the overall condition of the forest ecosystem (Rahman et al. 2011). 
Table 4. Diversity indices of the regenerating tree species in the HWS.

\begin{tabular}{lccc}
\hline Diversity indices & HWS $^{1}$ & CWS $^{2}$ & DDWS $^{3}$ \\
\hline Shannon-Wiener Diversity Index & 1.396 & 3.67 & 3.87 \\
Simpson's Dominance Index & 0.329 & 0.042 & 0.04 \\
Pielou's Species Evenness Index & 0.847 & 0.789 & 0.81 \\
Margalef's Richness Index & 1.871 & 12.86 & 15.27 \\
\hline
\end{tabular}

${ }^{1}$ Hazarikhil Wildlife Sanctuary (Present study); ${ }^{2}$ Chunati Wildlife Sanctuary (Hossain and Hossain 2014);

${ }^{3}$ Dudhpukuria-Dhopachari Wildlife Sanctuary (Hossain et al. 2013).

The present study reveals that natural regeneration potential of the HWS is moderate in terms of regeneration, composition and diversity though it is comparatively poor in both species and family diversity. The reasons responsible for the poor regenerating species composition, and diversity in the HWS are degradation of habitat, (e.g. change in land use, introduction of exotics, and other anthropogenic activities) that have damage most of the forest resources of Hazarikhil WS. Over exploitation of resources, e.g. illicit felling, encroachment, indiscriminate harvesting of tree species and non-timber forest products exert a significant negative impact on the regeneration of the HWS. However, considering the recent conservation initiatives of the wildlife sanctuary authority, it is expected to have positive impacts on the forest coverage and regeneration potentials. The area is rich in soil seed bank of tree species and regeneration may be enhanced if fire can be controlled during dry season.

\section{ACKNOWLEDGEMENTS}

The authors are thankful to the Planning and Development Office, University of Chittagong for providing the research grant. Special thanks to Bangladesh Forest Research Institute (BFRI) for identifying the plant species.

\section{REFERENCES}

Abdullah, R. M., T. Noguchi and N. Mohammad. 2007. Impact of participatory forest management (PFM) on socio-economic development in Bangladesh: a case study in the Madhupur Sal Forest. $J$. Forest Econ. 53(1): 46-56.

Ahmed, G. U., M. S. Newaz and A. B. Temu. 1992. Status of natural regeneration in the denuded hills of Chittagong, Bangladesh. Commonwealth Forestry Rev. 71(3/4): 178-182.

Ahmed, Z. U., Z. N. T. Begum, M. A. Hassan, M. Khondker, S. M. H. Kabir, M. Ahmad, A. T. A. Ahmed, A. K. A. Rahman and E. U. Haque. (eds.). 2008. Encyclopedia of Flora and Fauna of Bangladesh. Vol. 5-12. Asiatic Society of Bangladesh, Dhaka.

BBS (Bangladesh Bureau of Statistics). 2012. Population Census, Bangladesh Bureau of Statistics. http://www.bbs.gov.bd. Accessed 23 Sep 2018.

BFD (Bangladesh Forest Department). 2017. Management and Conservation- Legal Forest Land: District wise forest land information. Bangladesh Forest Department. http://bforest.gov.bd/site/page/837e6966-0fce-4274-a0d0-bcdfa49ce492/Legal-forest-land. Accessed 23 September 2018.

Dallmeier, F., M. Kabel and R. Rice. 1992. Methods for long term biodiversity inventory plots in protected tropical forests. In: F. Dallmeier (ed.). Long term monitoring of Biological Diversity in Tropical Forest Areas: Methods for Establishment and Inventory of Permanent plots. UNESCO, Paris, France., pp. 11-46. 
Elzinga, C. L., D. W. Salzer and J. W. Willoughby. 1998. Measuring and Monitoring Plant Populations. Bureau of Land Management, Denver, Colorado. 477 pp.

FAO. 2016. Forests and Agriculture: land-use challenges and opportunities, State of the World's Forests. Food \& Agriculture Organization, Rome, Italy.

Haque, S. M. S. and M. S. Alam. 1988. Some aspects of practicing the clear-felling followed by artificial regeneration system in the Cox's Bazar Forest Division. Chittagong Univ. Stud. Part II. 12(2): 87-95.

Hossain, M. K., A. K. Azad and M. K. Alam. 1999. Assessment of natural regeneration status in a mixed tropical forest at Kaptai of Chittagong Hill Tracts (South) Forest Division. Chittagong Univ. J. Sci. 23(1): 73-80.

Hossain, M. A., M. K. Hossain and M. D. Hossain. 2013. Natural regeneration potential of native tree species in Dudhpukuria-Dhopachori Wildlife Sanctuary of Chittagong, Bangladesh. Bangladesh J. Forest Sci. 32(2): 15-25.

Hossain, M. K. 2001. A review of forest biodiversity conservation in Bangladesh. Journal of Forestry and Environment. 1(1): 102-110.

Hossain, M. K., M. S. Alam and M. A. Hossain. 2017. Conservation of Threatened Tree Species in Chittagong University Campus. Arannayk Foundation, Dhaka, Bangladesh.

Hossain, M. K. and M. A. Hossain. 2014. Biodiversity of Chunati Wildlife Sanctuary: Flora. Bangladesh Forest Department and Arannayk Foundation, Dhaka. 176 pp.

IMF (International Monetary Fund). 2013. Bangladesh: Poverty Reduction Strategy Paper (IMF Country Report No. 13/63). Wahington, D.C, U.S.A.

Kamruzzaman, M., M. A. Hossain, M. Jannat and M. K. Hossain. 2018. Regeneration Status of Babu Para Village Common Forest (VCF) in Bandarban District, Bangladesh. AASCIT J. Biol. 4(1): 15-20.

Kwit, C. and W. J. Platt. 2003. Disturbance history influences regeneration of non-pioneer understory trees. Ecology. 84(10): 2575-2581.

Margalef, R. 1958. Information theory in ecology. Computers \& Chemistry 3: 36-71.

Misra, R. 1968. Ecology Workbook. New Delhi, India: Oxford and IBH Publishing.

Motaleb, M. A. and M. K. Hossain. (2007). Studies on natural regeneration of a semi-evergreen forest of Chittagong (South) Forest Division, Bangladesh. J. Forestry Environ. 5: 95-101.

Mittermeier, R. A., N. Myers, J. B. Thomsen, G. A. Da Fonseca and S. Olivieri. 1998. Biodiversity hotspots and major tropical wilderness areas: approaches to setting conservation priorities. Conserv. Biol. 12(3): 516-520.

Mori, S. A., B. M. Boom, A. M. Carvalino and D. Santos. 1983. The ecological importance of Myrtaceae in eastern Brazilian wet forest. Biotropica. 15: 68-70.

Nishat, A. and S. R. Biswas. 2005. Community-based restoration of degraded tropical hill forests: Experiences from Krykhong Para, Chittagong Hill Tracts, Bangladesh. Bul. Natl. Inst. Ecol. 16: 1-11.

Osman, K. T. 2013. Soils: Principles, Properties and Management. London. Springer Science \& Business Media Dordrecht, London. 271 pp. 
Pielou, E. C. 1984. The interpretation of ecological data: a primer on classification and ordination. John Wiley \& Sons, Canada.

Rahman, M. H., M. A. S. A. Khan, B. Roy and M. J. Fardusi. 2011. Assessment of natural regeneration status and diversity of tree species in the biodiversity conservation areas of Northeastern Bangladesh. J. Forestry Res. 22(4): 551.

Rashid, M. H., M. A. Rahman and C. C. Wilcock. 2000. Diversity, ecology, distribution and ethnobotany of the Apocynaceae of Bangladesh. Bangladesh J. Plant Taxon. 7(2): 59-76.

Reddy, C. S., S. Babar, G. Amarnath and C. Pattanaik. 2011. Structure and floristic composition of tree stand in tropical forest in the Eastern Ghats of northern Andhra Pradesh, India. J. Forestry Res. 22(4): 491.

Shafroth, P. B., J. C. Stromberg and D. T. Patten. 2002. Riparian vegetation response to altered disturbance and stress regimes. Ecol. Appl. 12(1): 107-123.

Shahid, S. 2010. Rainfall variability and the trends of wet and dry periods in Bangladesh. Int. J. Climatol. 20: 2299-2313.

Shannon, C. E. and W. Weiner. 1963. The mathematical theory of communication Urban University Illinois Press. 125pp.

Shukla, R. S. and P. S. Chandal. 2000. Plant Ecology and Soil Science (9th edn.). Ramnagor: S. Chand and Company Limited, New Delhi, India., pp. 121-376.

Simpson, E. H. 1949. Measurement of diversity. Nature. 163: 688.

Stanford, C. B. 1991. The capped langur in Bangladesh: behavioral ecology and reproductive tactics. Karger Medical and Scientific Publishers. https://books.google.com.bd/books?isbn=380555396X

Williams, G. M. 1991. Techniques and fieldwork in Ecology. Collins Educational, London, UK., 156 pp. 
